\title{
First Croatian Prospective Peripheral Artery Disease Registry (CRO-PAD): What have we learned in the past 10 years?
}

\author{
(D) Mislav Vrsalovićc ${ }^{12}$, \\ (iDTonći Batinićc \\ (DNikola Kos ${ }^{2}$, \\ (D)Ksenija Vučur ${ }^{3}$, \\ (DBoris $\mathrm{Car}^{2}$ \\ 'University of Zagreb School \\ of Medicine, Zagreb, Croatia \\ ${ }^{2}$ University Hospital Centre \\ "Sestre milosrdnice“, Zagreb, \\ Croatia \\ ${ }^{3}$ University Hospital Merkur, \\ Zagreb, Croatia
}

\begin{abstract}
KEYWORDS: peripheral artery disease, chronic limb threatening ischemia, major adverse cardiovascular events, polyvascular disease.

CITATION: Cardiol Croat. 2021;16(1-2):75. | https://doi.org/10.15836/ccar2021.75

*ADDRESS FOR CORRESPONDENCE: Mislav Vrsalović, Klinički bolnički centar Sestre milosrdnice, Vinogradska 29, HR-10000 Zagreb, Croatia. / Phone: +385-91-5301478 / E-mail: mislav.vrsalovic@gmail.com

ORCID: Mislav Vrsalović, https://orcid.org/0000-0002-8432-404X • Tonći Batinić, https://orcid.org/0000-0002-8431-6963 Nikola Kos, https://orcid.org/0000-0001-8829-2543• Ksenija Vučur, https://orcid.org/0000-0002-8255-4933 Boris Car, https://orcid.org/0000-0002-1859-3102

\section{|IIIIIIIIIIIIIIIIIIIIIIIIIIIIIIIIIIIIIIIIIIIIIIIIIIIIIIIIIIIIIIIIIIIIIIIIIIIIIIIIIIIIIIIIIIIIIIIIIIIIIIIIIII}

Aim: Patients with peripheral artery disease (PAD) are at very high risk of cardiovascular events..$^{1-3}$ The first Croatian Prospective Peripheral Artery Disease Registry (CRO-PAD) was created in 2010, with the aim to collect, organize and present data about patients with PAD. The purpose was to evaluate risk factors, prognosticators, longitudinal outcomes, and therapeutic development in order to improve patients' healthcare and disease outcomes.
\end{abstract}

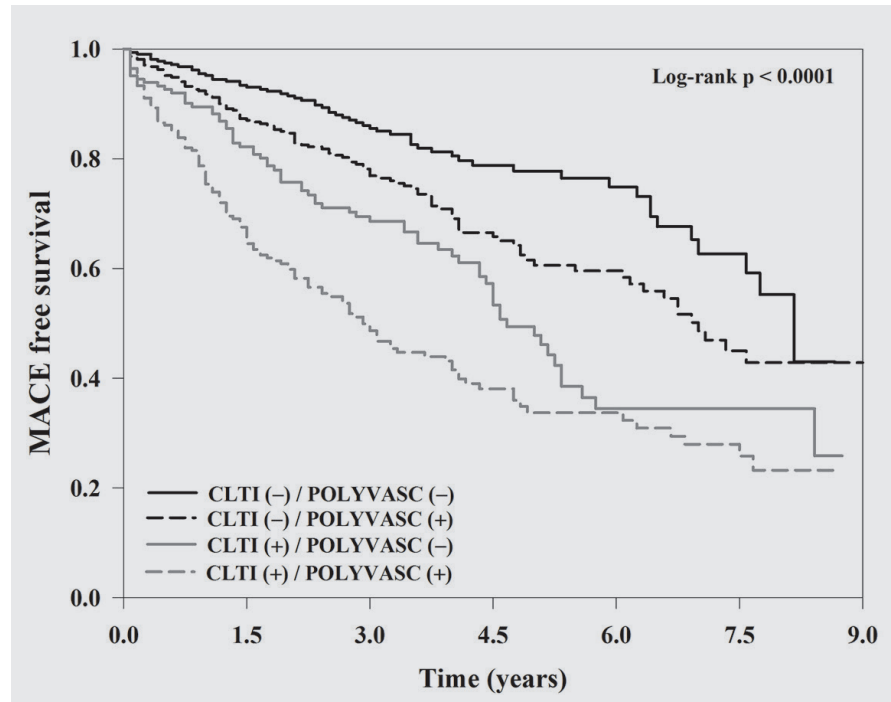

FIGURE 1. Cumulative major adverse cardiovascular events (MACE) free survival in 1084 symptomatic PAD patients according to polyvascular involvement (POLYVASC) and chronic limb threatening ischemia (CLTI).

\section{RECEIVED:}

December 4, 2020

ACCEPTED:

December 18, 2020

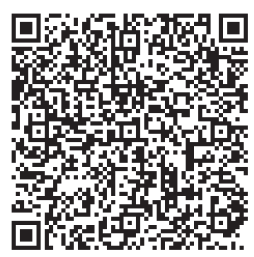

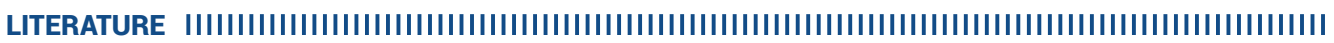

1. Vrsalović M, Vučur K, Car B, Krčmar T, Vrsalović Presečki A. C-reactive protein, renal function, and cardiovascular outcome in patients with symptomatic peripheral artery disease and preserved left ventricular systolic function. Croat Med J. 2015 Aug;56(4):351-6. https://doi.org/10.3325/cmj.2015.56.351

2. Vrsalović M, Vučur K. Diabetes and Critical Limb Ischemia: The Deadly Duo in Patients with Symptomatic Peripheral Artery Disease. Acta Clin Croat. 2016 Jun;55(2):240-6. https://doi.org/10.20471/acc.2016.55.02.09

3. Vrsalović M, Presečki AV. Atrial fibrillation and risk of cardiovascular events and mortality in patients with symptomatic peripheral artery disease: A meta-analysis of prospective studies. Clin Cardiol. 2017 Dec;40(12):1231-1235. https://doi.org/10.1002/clc.22813 